\title{
CONSTRUCTION OF AN ISLAMIC INDEX USING THE MEDIAN CRITERION OF QUANTITATIVE FILTERS: APPLICATION TO THE AFRICAN STOCK EXCHANGE
}

\author{
Moustapha Balde \\ Department of Economics \\ Gaston Berger University, Saint-Louis, Senegal \\ E-mail: balde.moustapha@ugb.edu.sn \\ (iDhttps://orcid.org/0000-0002-5951-8627 \\ Mamadou A. Konte \\ Department of Economics \\ Gaston Berger University, Saint-Louis, Senegal \\ E-mail: mamadou-abdoulaye.konte@ugb.edu.sn \\ (iD https://orcid.org/0000-0002-2499-3313
}

Received: August 07, 2021 Accepted: October 09, 2021 Online Published: November 14, 2021

DOI: $10.46281 /$ ijibfr.v8i1.1436

URL: https://doi.org/10.46281/ijibfr.v8i1.1436

\begin{abstract}
Many techniques, combining qualitative and quantitative filters, have been proposed in the literature to construct an Islamic index on financial stock exchange. These are often based on fixed thresholds to define quantitative filters. However, as companies do not have the same characteristics from one sector to another, it is necessary to have heterogeneous thresholds for filtering purposes. Our contribution, here, is to propose a methodology which integrates this fact by using the median (statistic) criterion which is much more robust than the average criterion (vis$\grave{a}$-vis the presence of extreme values) but also the median statistic is consistent with the Wassatiya principle (50\% of the way) than the 33\% fraction used by many studies.
\end{abstract}

Keywords: Islamic Finance, Median Filtering, Qualitative Filtering, Quantitative Filtering, Stock Market Index.

JEL Classification Codes: G10, G11, G12, G14, G53.

\section{INTRODUCTION}

Islamic finance is based on the principles of "sharia". It has established itself as a financing alternative to the conventional system. Its evolution has led to the creation of new index.

A stock exchange index is defined as an indicator that measures the evolution over time of the performance of a stock market, a sector of activity or a sampled portfolio, Topsacalian (2000). In other words, it is the weighted or unweighted average of the prices of the panels of stocks, 
grouped on the basis of their zone, their country and / or their sector and / or their capitalization. This definition is broad enough to leave the door open to the creation of multiple stock market indices.

The strong demand for Islamic index has accelerated the launch of other Islamic index by other operators with more or less extensive coverage of geographic areas outside Africa.

The specificity of Africa in Islamic finance is mainly due to the importance of its Muslim community. It turns out that there are wealthy Muslims in Africa who respect Islamic injunctions in financial transactions (Koita \& Diaw, 2014). However, there are no "Sharia" compliant clues. This African characteristic constitutes one of the major symbolic arguments in favor of the development of African-style Islamic finance. Thus, the creation of an Islamic sector stock exchange index would be one of the necessary adjustments to strengthen its competitiveness in this sector.

The Islamic index most covered in articles are American, European and Asian indices. In our research, we only encountered three studies in Africa. Koita and Diaw (2014) investigated the possibility of investing in BRVM using the filtering method of the Islamic FTSE Global Shariah Equity Index. Mbengue (2017) proposed an index from the stock exchanges of Ghana, Nigeria and the BRVM using the S\&P methodological guide. Ndiaye (2019) studied the possibility of attracting the investment of Gulf countries in the financial centers of Ghana, Nigeria, Morocco by applying the filtering of the DJIMI index.

Our study proposes to use the statistic of median as a filtering method. To the best of our knowledge, this is a first paper that uses the median statistic. Indeed, companies do not have the same characteristics from one sector to another, it is necessary to have heterogeneous thresholds for the purposes of filtering. Our contribution, here, is to propose a methodology which integrates this fact by using the median statistic criterion which is much more robust than the average/mean statistic but also the median is in coherence with the principle of "wassatiya" (golden mean) than the fraction of $33 \%$ used by many studies.

In view of the initiatives taken by the Central Bank of West African States (CBWAS) to adapt banking regulations in order to take charge of the specificities of Islamic finance, the efforts made by the Islamic Bank of Development (IBD), applying the Islamic filtering in the creation of a sector stock market index is appropriate.

In the rest of this research, we will first present the data and the new methodology. Finally, we will present the findings and the comparison with another the existing methodology: DJIMI.

\section{Data}

\section{DATA AND METHODOLOGY TO CONSTRUCT A FINANCIAL INDEX}

In the selection of "Sharia-compatible" shares, we use as a pool of values the 1442 companies making up the 17 stock exchanges (South Africa, Botswana, BRVM, Egypt, Ghana, Keyna, Malawi, Morocco, Mauritius, Namibia, Nigeria, Uganda, Rwanda, Tanzania, Tunisia, Zambia and Zimbabwe).

To calculate the ratios, it was necessary to take into account the annual standardized balance sheets over seven financial years (2009 to 2015), the average monthly stock market price over 84 months of study as well as the number of shares of each of the listed companies.

The number of shares multiplied by the average monthly price (from 01/01/2009 to $12 / 31 / 2015$ ) is used to calculate the market capitalization. This gives us three annual values, one for each of the three ratios. A company integrates the Islamic index over the seven years as long as it scrupulously respects each of the filters associated with the three ratios. 


\section{Methodology}

For a share to be included in this index, it must pass the qualitative and quantitative filters. Indeed, the introduction of the qualitative filter consists in carrying out a sectoral exclusion.

The quantitative filter completes the qualitative filter for a better selection of share and it consists in sorting the companies to keep only those whose financial structure is able to meet the requirements expressed in the form of ratios.

To remain in compliance with the principles of "Sharia", "Sharia" committees impose a number of criteria in terms of liquidity, claims and debt on share traded on financial markets. This filter is also expressed as a ratio.

Among the methods for selecting stocks for a stock market index in Islamic finance, the most commonly accepted criteria, within the meaning of El Khamlichi (2012), are those retained by the "sharia" committee of DJIMI (Debt Ratio, Liquidity Ratio and Debt Ratio).

Unlike previous works, we have chosen to conduct research that better reflects the specificities and needs of Africa in terms of stock markets. Indeed, the ratios applied on international stock exchange differ from one index to another, from one country to another or from one continent to another.

After the qualitative filter, we proceed to a sector classification of listed companies. Then, we take two approaches. The first is to calculate the median statistic over all the companies that have passed the qualitative filter. The second is to calculate the median statistic by business sector that has passed the first filter. Finally, for both approaches, an asset is selected if the value of its ratio is less than or equal to the median statistic of the ratios of selected companies (either all or by sector).

We use the median statistic for three main reasons:

- A statistical reason: it is more robust than the average in the face of extreme values.

- A religious reason: the median statistic is a principle of Islam which is the golden mean or "wassatiya" to define the threshold of acceptance / rejection.

- A financial reason: using the median statistic allows the portfolio to be diversified.

Table 1. The filter of DJIM and the filters of the medians

\begin{tabular}{|l|c|l|l|}
\hline Filters & Dow Jones Islamic Market Index & $\begin{array}{l}\text { General } \\
\text { Median }\end{array}$ & $\begin{array}{l}\text { Sectoral } \\
\text { Median }\end{array}$ \\
\hline $\begin{array}{l}\text { Debt Ratio } \\
(\mathrm{RE})\end{array}$ & $\frac{\text { total debts }}{\mathrm{AMC} 24 \text { last months }}<33 \%$ & $70 \%$ & $33 \%$ \\
\hline $\begin{array}{l}\text { Liquidity Ratio } \\
(\mathrm{RL})\end{array}$ & $\frac{\text { total cash and interest }}{1}<33 \%$ & $10 \%$ & $70 \%$ \\
\hline $\begin{array}{l}\text { Debt Ratio } \\
(\mathrm{RC})\end{array}$ & $\frac{\text { AMC 24 last months }}{\text { total receivables }}<33 \%$ & $18 \%$ & $70 \%$ \\
\hline
\end{tabular}

$\mathrm{Nb}: \mathrm{AMC}=$ Average Market Capitalisation

Total cash and interest-bearing securities (1)

Source: Construction of the authors from the financial database and documents on DJIM

Table 1 shows that the general median statistic and the sectoral median statistic, unlike the DJIMI index (33\%), show disparities in the thresholds of the ratios. Concerning the general median 
statistic, the thresholds varying from $10 \%$ to $70 \%$. Compared to the sectoral median statistic, the threshold for ratios varying from $33 \%$ to $70 \%$.

\section{The Result of The Extra-Financial Filter}

\section{FINDINGS AND ANALYSIS}

The initial goal was to carry out a complete analysis of 37 stock exchanges, due to lack of data, 17 stock markets were studied.

The original purpose was to perform a comprehensive analysis of the thirty-seven (37) stock exchanges in Africa, but the research limit confined us to seventeen (17) stock markets.

Of these, three (Mauritius (SEM), Uganda (USE) and Rwanda (RSE)) were automatically eliminated due to a lack of data. Unfortunately, all the companies that make up the fourteen (14) remaining exchanges that passed the first test could not be analyzed in the second screening. This is due to the unavailability of financial statements and also to the absence of detailed items (financial result) from the companies' financial statements.

Of the 1442 companies listed on the 17 stock exchanges, only 418 have passed the first test where $29 \%$ of companies are potentially compatible with "Sharia". This is the most restrictive filter in this study.

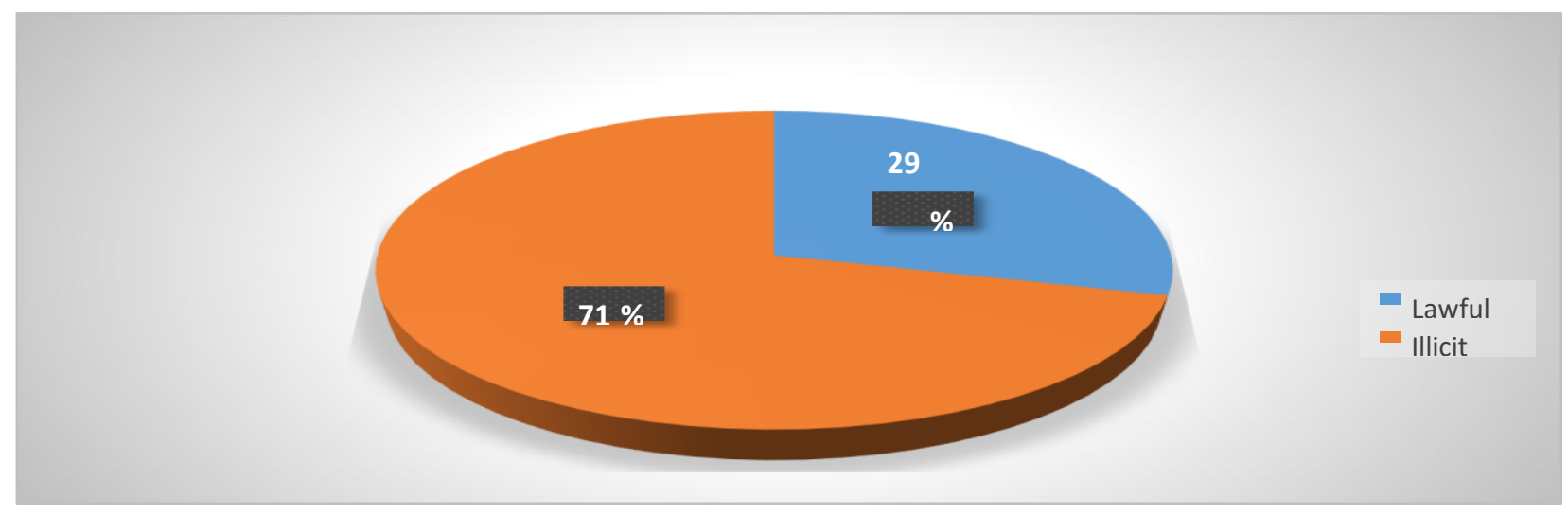

Figure 1. Finding of the extra-financial filter

The $71 \%$ are made up of companies whose activities are related to finance, insurance and / or leisure as being the most "illicit" sectors from the point of view of compatibility with the requirements of "Sharia". Although this configuration is not surprising, it can be explained by the very nature of their activities and therefore by their instinctive propensity to expose themselves to "riba".

\section{Finding of the Quantitative Filter (Or Financial)}

Table 2. Findings by sector

\begin{tabular}{|l|c|c|c|}
\hline Sectors & DJIM & General Median statistic & Sectoral Median statistic \\
\hline Agricultural & 0 & 0 & 1 \\
\hline Finance & 7 & 9 & 8 \\
\hline Industry & 24 & 30 & 24 \\
\hline Services & 18 & 16 & 20 \\
\hline Telecommunication & 3 & 3 & 1 \\
\hline
\end{tabular}




\begin{tabular}{|l|c|c|c|}
\hline Transport & 1 & 1 & 2 \\
\hline Other & 0 & 0 & 1 \\
\hline Total & 53 & 59 & 57 \\
\hline
\end{tabular}

Source: Construction of the authors from the financial database

Among the 373 companies submitted to the financial test, $14.21 \%$ (or 53) passed the DJIMI filter, $15.82 \%$ (or 59) for the general median filter and $15.3 \%$ (or 57) for the sectoral median filter. This represents approximately $3.67 \%, 4.1 \%$ and $4 \%$ respectively of listed companies overall.

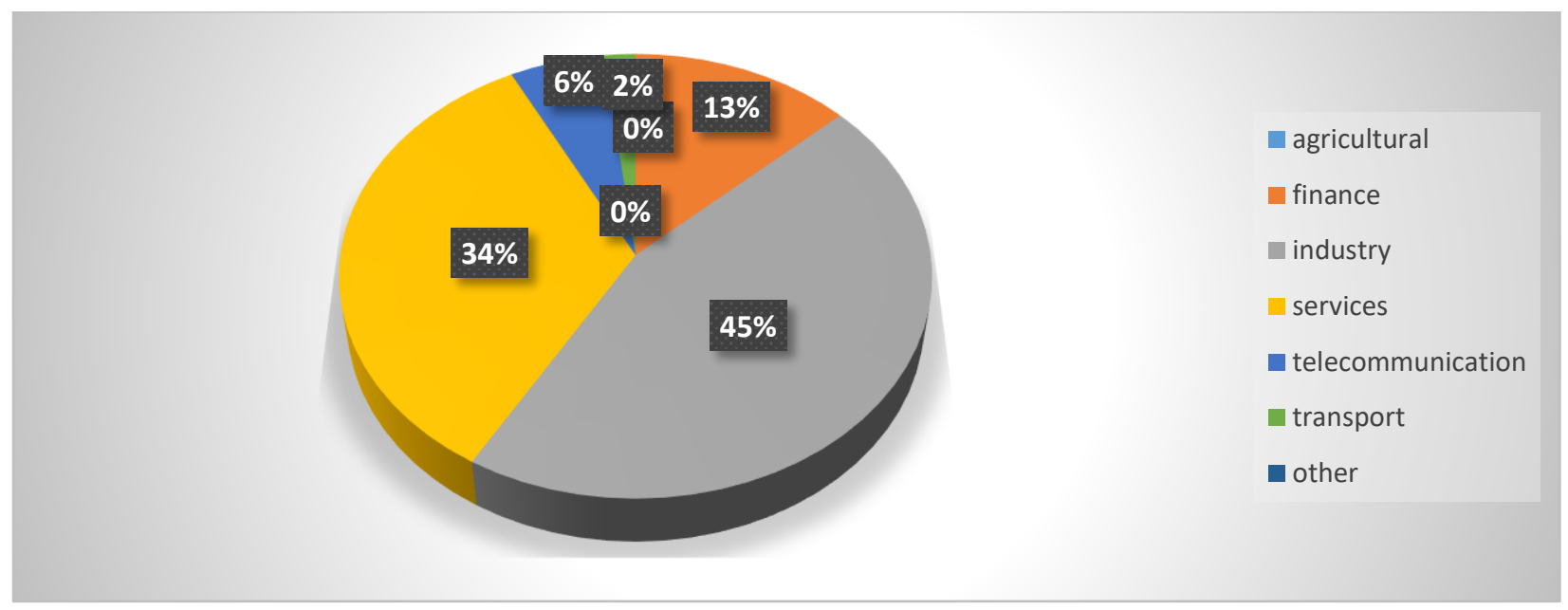

Figure 2. Standard islamic filter from DJIM

With DJIM filtering, we have five lines of business. The industrial and service sectors represent $79 \%$ of listed companies having passed both tests, i.e., 24 and 18 companies respectively. The remaining 21\% (11 companies) are split between the finance (13\%), telecommunications $(6 \%)$ and transport $(2 \%)$ sectors.

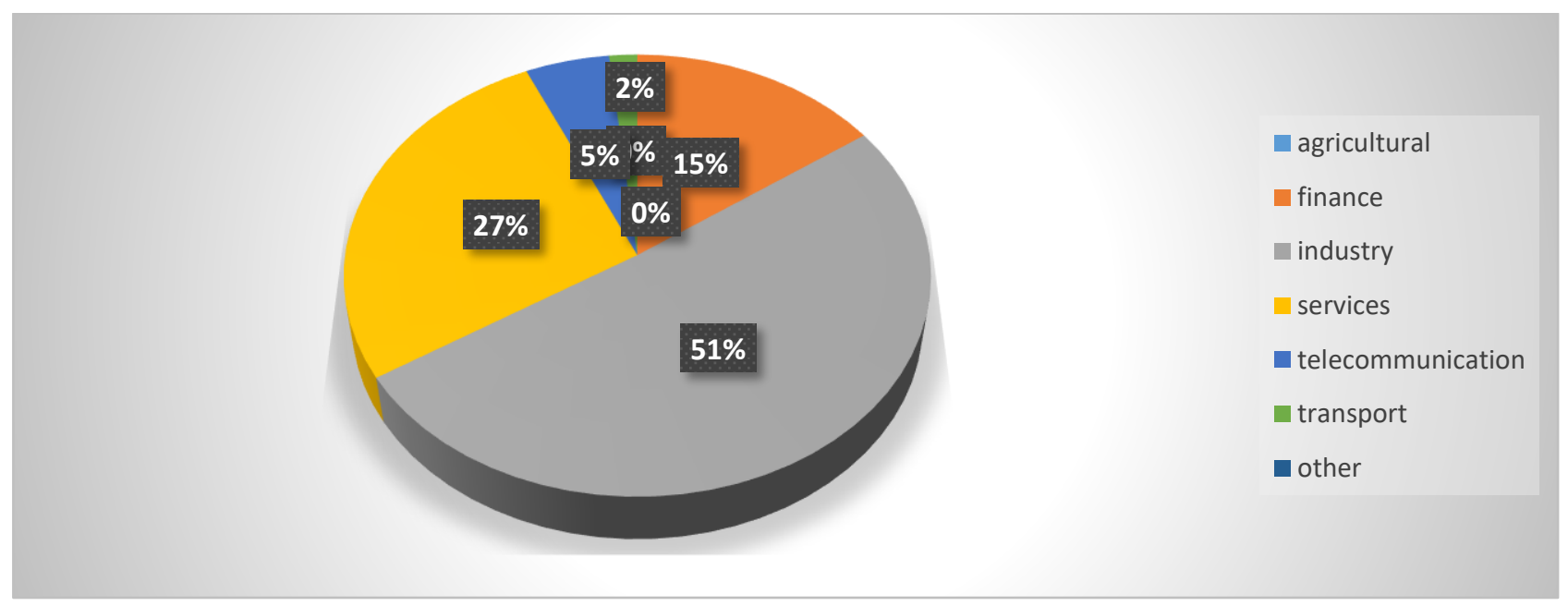

Figure 3. Global median filter

Regarding the filtering of the general median, we end up with five sectors. They break down as follows in terms of the number of listed companies: 30 companies in the industrial sector, 
or $51 \%$. It is followed by the service sector with 16 companies, or $27 \%$ of the 59 selected, followed by the finance sector with $15 \%$ or 9 companies. The telecommunications and transport sectors accumulate only $7 \%$, i.e., 04 and 01 companies respectively.

For the sectoral median filter, the industrial sector records $42 \%$ of the companies which passed both tests. It is followed by the service sector with $35 \%$ of companies among the 57 retained by the second filter. The finance sector occupies the third position with $14 \%$. The remaining sectors (agriculture, telecommunications, transport and others) account for only $9 \%$ of companies.

The ones that failed the second quantitative filters represent approximately $22.2 \%$ for the DJIMI, $21.77 \%$ for the general median and $21.9 \%$ for the sectoral median, or respectively 320 ; 314 and 316 companies.

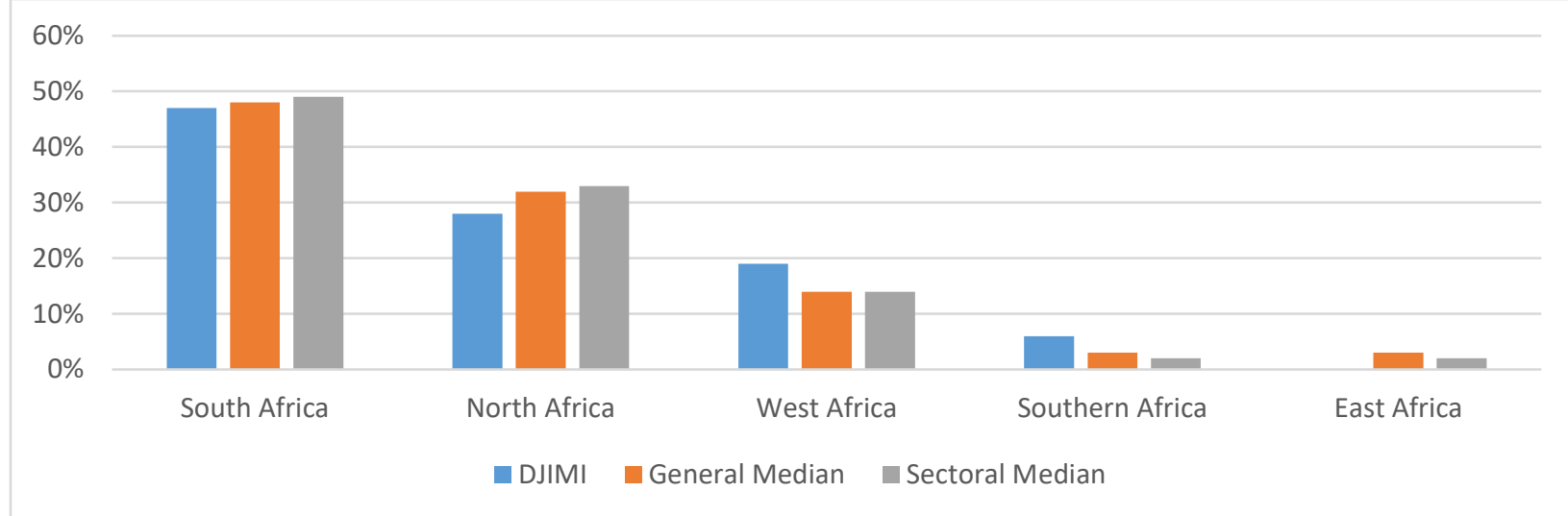

Figure 4. listed companies by geographic area

In terms of geographical distribution for the three methods (respectively DJIMI, general median and sectoral median), South Africa dominates with $47 \%, 48 \%$ and $49 \%$ of the companies among those which have passed the qualitative and quantitative filters. The second place is occupied by North Africa with 28\%, 32\% and 33\%, of the lot of values retained. West Africa is third with $19 \%, 14 \% 14 \%$ of companies that have passed the filters. Southern Africa records $6 \%$, $3 \%$ and $2 \%$. On the other hand, East Africa does not register any company for the DJIMI filter. Nevertheless, it $3 \%$ and $2 \%$ by general and sectoral medians.

\section{CONCLUSION}

Our paper aimed at applying a new filtering methodology in the process of creating an Islamic index in order to make the Africa zone more competitive in attracting Muslim and foreign capital. The study has been carried out taking into account a pool of stock exchanges from 16 countries and a regional stock exchange (BRVM) in Africa.

We have applied the qualitative and quantitative filters. For the quantitative filter, we have adopted three methods: the DJIMI method, filtering by general median statistic and filtering by sectoral median statistic. This approach produced a number of results.

The qualitative filtering has led to the exclusion of $71 \%$ of the stocks making up the 17 African financial markets covered by the study. Quantitative filtering has resulted in the exclusion of $22.2 \%$ for the DJIMI, $21.77 \%$ for the general median and $21.9 \%$ for the sectoral median of listed companies. Those who have passed this quantitative filter respectively represent $14.21 \%, 15.82 \%$ and $15.3 \%$ of the companies subjected to this test. 
South Africa leads the way in terms of the geographic distribution of businesses. The second place is occupied by North Africa. Next comes West Africa. Finally, Southern Africa and East Africa each of these zones counts a company and this, for the three methods.

The study has proven that the African stock exchange is a market where Muslims could invest in at least 53, 59 and 57 listed companies during the study period (2009-2015) with respectively the methods of DJIM, from the statistic of median in general and sectoral case.

In addition, we can retain that the financial index with the sectoral median (statistic) method constitutes the most diversified portfolio compared to the others. On the other hand, the general median statistic counts more listed values.

Finally, beyond the choice of filtering by the median (general or sectoral), it is necessary to rethink the relevant filtering process to take into account the specifics of African companies in terms of Islamic financial investment. The interest of applying a filter in the process of creating an Islamic stock index in Africa's financial center does not only have a symbolic dimension aimed at sending a positive signal to African or foreign Muslim investors; but to prove that this index once available, would have financial arguments of its own.

\section{AUTHOR CONTRIBUTIONS}

Conceptualization: Moustapha Balde, Mamadou A. Konte

Data Curation: Moustapha Balde, Mamadou A. Konte

Formal Analysis: Moustapha Balde, Mamadou A. Konte

Funding Acquisition: Moustapha Balde, Mamadou A. Konte

Investigation: Moustapha Balde, Mamadou A. Konte

Methodology: Moustapha Balde, Mamadou A. Konte

Project Administration: Moustapha Balde

Resources: Moustapha Balde, Mamadou A. Konte

Software: Mamadou A. Konte

Supervision: Moustapha Balde, Mamadou A. Konte

Validation: Moustapha Balde, Mamadou A. Konte

Visualization: Moustapha Balde, Mamadou A. Konte

Writing - Original Draft: Moustapha Balde, Mamadou A. Konte

Writing - Review \& Editing: Moustapha Balde, Mamadou A. Konte

\section{CONFLICT OF INTEREST STATEMENT}

The authors declare that they have no competing interests.

\section{ACKNOWLEDGMENTS}

All authors contributed equally to the conception and design of the study. We thank Professor Lamine Mbengue, Dr. Alioune Badara Mbengue and Mr. Bassirou Goudiaby for their comments and suggestions that helped to improve the quality of this paper.

\section{REFERENCES}

Ahmad, Z., \& H., Ibrahim. (2002). A Study of Performance of The KLSE Syariah Index. Malaysian Management Journal, 6(1 \& 2), 25-34.

El Khamlichi, A. (2012). Ethics and performance: the case of stock market indices and investment funds in Islamic finance. University of Auvergne-Clermont-Ferrand I. 
Koita, M., \& Diaw, A. K. (2014). Islamic investment in the West African Economic and Monetary Union (UEMOA) regional financial market: an application of Islamic filtering. Studies in Islamic Economics, 7(2), 19-36.

Mbengue, M. L. (2017). Creation of an Islamic stock index in West Africa. Research in International Business and Finance, 41, 105-108.

Ndiaye, O. (2019). Creation of a common Islamic stock market index on the financial centers of ECOWAS and Morocco: Methodology. University review without borders for an open society, (Volume 14, December, 2019)

Topsacalian, P. (2000). Stock market indices. Economica, Paris. 2000. "Update on ... stock market indices. Banking \& Markets, 47, 54-58.

\section{Appendix A: DJIMI}

\section{APPENDICES}

\begin{tabular}{|l|l|}
\hline \multicolumn{1}{|c|}{ FIRMS } & SECTORS \\
\hline Reunert Ltd (RLO SJ) & Finance \\
\hline Oceana Group Ltd (OCE SJ) & Finance \\
\hline Assore Ltd (ASR SJ) & Finance \\
\hline Anglo American Platinum Ltd (AMS SJ) & Finance \\
\hline Impala Platinum Holdings Ltd (IMP SJ) & Finance \\
\hline Shoprite Holdings Ltd (SHP SJ) & Finance \\
\hline Truworths Internationa Ltd (TRU SJ) & Finance \\
\hline Bauba Platinul Ltd (BAU SJ) & Industry \\
\hline Mazor Group Ltd (MZR SJ) & Industry \\
\hline Nutritional Holding Ltd (NUT SJ) & Industry \\
\hline SacOil Holdings Ltd (SCL SJ) & Industry \\
\hline Northam Platinum Ltd (NHM SJ) & Industry \\
\hline AVI Ltd (AVI SJ) & Industry \\
\hline African Rainbow Minerals Ltd (ARI SJ) & Industry \\
\hline Société des Caoutchoucs de Grand-Bereby (SOGC BC) & Industry \\
\hline Société Africaine de Plantations d'Heveas SA (SPHC BC) & Industry \\
\hline Paints \& Chemical Industry Co (PACH EY) & Industry \\
\hline South Valley Cement (SVCE EY) & Industry \\
\hline Societe Metallurgique D'imiter (SMI MC) & Industry \\
\hline Centrale Danone (CDA MC) & Industry \\
\hline Cie Miniere de Touissit (CMT MC) & Industry \\
\hline NASCO Allied Indudtries PLC (NASCON NL) & Industry \\
\hline Nestle Nigeria PLC (NESTLE NL) & Industry \\
\hline Morison Industries PLC (MORISON NL) & \\
\hline & \\
\hline
\end{tabular}




\begin{tabular}{|l|l|}
\hline Unilever Nigerian PLC (UNILEVER NL) & Industry \\
\hline PZ Cussons Nigeria PLC (PZ NL) & Industry \\
\hline $\begin{array}{l}\text { Societe Industrielle d'Appareillage et de Materiels Electriques } \\
\text { (SIAME TU) }\end{array}$ & Industry \\
\hline GIF Filter SA (GIF TU) & Industry \\
\hline Societe de Production Agricole Tzboulba (SOPAT TU) & Industry \\
\hline Lafarge Cement Zambia PLC (LAFA ZL) & Industry \\
\hline Zambia Sugar PLC (ZMSG ZL) & Services \\
\hline Mr Price Group Ltd (MRP SJ) & Services \\
\hline Tiger Brands Ltd (TBS SJ) & Services \\
\hline ISA Holding Ltd (ISA SJ) & Services \\
\hline Italtile Ltd (ITE SJ) & Services \\
\hline Adcock Ingram Holdings Ltd (AIP SJ) & Services \\
\hline Advtech Ltd (ADH SJ) & Services \\
\hline Woolworths Holdings Ltd/South Africa (WHL SJ) & Services \\
\hline Famous Brands Ltd (FBR SJ) & Services \\
\hline ARB Holdings Ltd (ARH SJ) & Services \\
\hline Spur Corp Ltd (SUR SJ) & Services \\
\hline Engen Botswana Ltd (ENGN BG) & Services \\
\hline Servair Abidjan ABJCCI BC & Services \\
\hline CFAO motors Cote d'Ivoire (CFAC BC) & Services \\
\hline Alexandria Containers \& Goods (ALCN EY) & Services \\
\hline Assiut Islamic Trading (AITG EY) & Services \\
\hline Auto Hall (ATH MC) & Services \\
\hline Automobile Reseau Tunisien et Services (ARTES TU) & Services \\
\hline Essoukna (SOKNA TU) & Telecommunication \\
\hline Caxton and CTP Publishers and Printers Ltd (CAT SJ) & Telecommunication \\
\hline Sonatel (SNTS BC) & Telecommunication \\
\hline Maroc Telecom (IAM MC) & Transport \\
\hline Societe de Transport Hydrocarbures par Pipelines (STPIL TU) & \\
\hline
\end{tabular}

\section{Appendix B: General Median}

\begin{tabular}{|l|l|}
\hline \multicolumn{1}{|c|}{ FIRMS } & SECTORS \\
\hline Massmart Holding Ltd (MSM SJ) & Finance \\
\hline Aspen Pharmacare Holding Ltd (APN SJ) & Finance \\
\hline PPC Ltd (PPC SJ) & Finance \\
\hline Oceana Group Ltd (OCE SJ) & Finance \\
\hline Anglo American Platinum Ltd (AMS SJ) & Finance \\
\hline Impala Platinum Holdings Ltd (IMP SJ) & Finance \\
\hline
\end{tabular}




\begin{tabular}{|l|l|}
\hline Shoprite Holdings Ltd (SHP SJ) & Finance \\
\hline Truworths Internationa Ltd (TRU SJ) & Finance \\
\hline Metrofile Holdings Ltd (MFL SJ) & Finance \\
\hline Bauba Platinul Ltd (BAU SJ) & Industry \\
\hline Petmin Ltd (PET SJ) & Industry \\
\hline Astral Foods Ltd (ARL SJ) & Industry \\
\hline Nutritional Holding Ltd (NUT SJ) & Industry \\
\hline Harmony Gold Mining Co Ltd (HAR SJ) & Industry \\
\hline Incitec Pivot Ltd (IPL SJ) & Industry \\
\hline Northam Platinum Ltd (NHM SJ) & Industry \\
\hline AVI Ltd (AVI SJ) & Industry \\
\hline African Rainbow Minerals Ltd (ARI SJ) & Industry \\
\hline African Oxygen Ltd (AFX SJ) & Industry \\
\hline Gold Fields Ltd (GFI SJ) & Industry \\
\hline Sociéte des Caoutchoucs de Grand-Bereby (SOGC BC) & Industry \\
\hline Ismailia Misr Poultry Co (ISMA EY) & Industry \\
\hline Lecico Egypt SAE (LCSW EY) & Industry \\
\hline Upper Egypt Flour Mills (UEFM EY) & Industry \\
\hline ElSewedy Electic Co (SWDY EY) & Industry \\
\hline South Valley Cement (SVCE EY) & Industry \\
\hline Carbacid Investments Ltd (CBIL KN) & Industry \\
\hline Sonasid (SID MC) & Industry \\
\hline Societe Metallurgique D'imiter (SMI MC) & Industry \\
\hline Centrale Danone (CDA MC) & Industry \\
\hline Cie Miniere de Touissit (CMT MC) & Industry \\
\hline Lesieur Cristal (LES MC) & Industry \\
\hline Nestle Nigeria PLC (NESTLE NL) & Industry \\
\hline Morison Industries PLC (MORISON NL) & Industry \\
\hline Unilever Nigerian PLC (UNILEVER NL) & Industry \\
\hline Tripple GEE and Co PLC (TRIPPLEG NL) & Industry \\
\hline PZ Cussons Nigeria PLC (PZ NL) & Industry \\
\hline GIF Filter SA (GIF TU) & Industry \\
\hline Zambia Sugar PLC (ZMSG ZL) & Industry \\
\hline Mr Price Group Ltd (MRP SJ) & Services \\
\hline Tiger Brands Ltd (TBS SJ) & Services \\
\hline Adcock Ingram Holdings Ltd (AIP SJ) & Services \\
\hline Advtech Ltd (ADH SJ) & Services \\
\hline Famous Brands Ltd (FBR SJ) & Services \\
\hline Pioneer Foods Group Ltd (PFG SJ) & Services \\
\hline Clicks Group Ltd (CLS SJ) & \\
\hline Spur Corp Ltd (SUR SJ) & Services \\
\hline Servair Abidjan ABJCCI BC & Alexandria Containers \& Goods (ALCN EY) \\
\hline
\end{tabular}




\begin{tabular}{|l|c|}
\hline Assiut Islamic Trading (AITG EY) & Services \\
\hline El Kahera Housing (ELKA EY) & Services \\
\hline Maridive \& Oil Services SAE (MOIL EY) & Services \\
\hline Lafarge Africa PLC (WAPCO NL) & Services \\
\hline Automobile Reseau Tunisien et Services (ARTES TU) & Services \\
\hline Essoukna (SOKNA TU) & Services \\
\hline Safaricom Ltd (SAFCOM KN) & Telecommunication \\
\hline Telekom Networks Malawi Ltd (TNM MW) & Telecommunication \\
\hline Maroc Telecom (IAM MC) & Telecommunication \\
\hline Societe de Transport Hydrocarbures par Pipelines (STPIL TU) & Transport \\
\hline
\end{tabular}

\section{Appendix C: Sectoral Median}

\begin{tabular}{|l|l|}
\hline \multicolumn{1}{|c|}{ FIRMS } & SECTORS \\
\hline Northern Upper Egypt Development (NEDA EY) & Agricultural \\
\hline Stockis Nord Afrique (SNA MC) & Other \\
\hline Massmart Holding Ltd (MSM SJ) & Finance \\
\hline PPC Ltd (PPC SJ) & Finance \\
\hline Oceana Group Ltd (OCE SJ) & Finance \\
\hline Anglo American Platinum Ltd (AMS SJ) & Finance \\
\hline Impala Platinum Holdings Ltd (IMP SJ) & Finance \\
\hline Shoprite Holdings Ltd (SHP SJ) & Finance \\
\hline Truworths Internationa Ltd (TRU SJ) & Finance \\
\hline Metrofile Holdings Ltd (MFL SJ) & Finance \\
\hline Bauba Platinul Ltd (BAU SJ) & Industry \\
\hline Astral Foods Ltd (ARL SJ) & Industry \\
\hline Nutritional Holding Ltd (NUT SJ) & Industry \\
\hline Harmony Gold Mining Co Ltd (HAR SJ) & Industry \\
\hline Incitec Pivot Ltd (IPL SJ) & Industry \\
\hline Northam Platinum Ltd (NHM SJ) & Industry \\
\hline AVI Ltd (AVI SJ) & Industry \\
\hline African Rainbow Minerals Ltd (ARI SJ) & Industry \\
\hline African Oxygen Ltd (AFX SJ) & Industry \\
\hline Ismailia Misr Poultry Co (ISMA EY) & Industry \\
\hline Lecico Egypt SAE (LCSW EY) & Industry \\
\hline ElSewedy Electic Co (SWDY EY) & Industry \\
\hline South Valley Cement (SVCE EY) & Industry \\
\hline Carbacid Investments Ltd (CBIL KN) & Industry \\
\hline Societe Metallurgique D'imiter (SMI MC) & Industry \\
\hline Centrale Danone (CDA MC) & Industry \\
\hline
\end{tabular}




\begin{tabular}{|l|c|}
\hline Cie Miniere de Touissit (CMT MC) & Industry \\
\hline Nestle Nigeria PLC (NESTLE NL) & Industry \\
\hline Morison Industries PLC (MORISON NL) & Industry \\
\hline Unilever Nigerian PLC (UNILEVER NL) & Industry \\
\hline Tripple GEE and Co PLC (TRIPPLEG NL) & Industry \\
\hline PZ Cussons Nigeria PLC (PZ NL) & Industry \\
\hline GIF Filter SA (GIF TU) & Industry \\
\hline Zambia Sugar PLC (ZMSG ZL) & Industry \\
\hline Mr Price Group Ltd (MRP SJ) & Services \\
\hline Tiger Brands Ltd (TBS SJ) & Services \\
\hline Adcock Ingram Holdings Ltd (AIP SJ) & Services \\
\hline Advtech Ltd (ADH SJ) & Services \\
\hline Famous Brands Ltd (FBR SJ) & Services \\
\hline Pioneer Foods Group Ltd (PFG SJ) & Services \\
\hline Crookes Brothers Ltd (CKS SJ & Services \\
\hline Clicks Group Ltd (CLS SJ) & Services \\
\hline Spur Corp Ltd (SUR SJ) & Services \\
\hline Servair Abidjan ABJCCI BC & Services \\
\hline CFAO motors Cote d'Ivoire (CFAC BC) & Services \\
\hline Palm Hills Developments SAE (PHDC) & Services \\
\hline Alexandria Containers \& Goods (ALCN EY) & Services \\
\hline Assiut Islamic Trading (AITG EY) & Services \\
\hline El Kahera Housing (ELKA EY) & Services \\
\hline Maridive \& Oil Services SAE (MOIL EY) & Services \\
\hline Auto Hall (ATH MC) & Services \\
\hline Lafarge Africa PLC (WAPCO NL) & Services \\
\hline Automobile Reseau Tunisien et Services (ARTES TU) & Services \\
\hline Essoukna (SOKNA TU) & Services \\
\hline MTN Group Ltd (MTN SJ) & Telecommunication \\
\hline Grindrod Ltd (GND SJ) & Transport \\
\hline Societe de Transport Hydrocarbures par Pipelines (STPIL TU) & Transport \\
\hline
\end{tabular}

\section{Copyrights}

Copyright for this article is retained by the author(s), with first publication rights granted to the journal. This is an open-access article distributed under the terms and conditions of the Creative Commons Attribution license (https://creativecommons.org/licenses/by/4.0). 